\title{
THE ROLE OF RURAL AREAS IN THE CREATION OF ECO-RESILIENT SUBURBS OF WARSAW
}

\author{
Justyna Zdunek-Wielgołaska ${ }^{\boxplus}$, Anna Grabowska \\ Faculty of Architecture, Warsaw University of Technology
}

\begin{abstract}
The aim of the article is to present alternatives to the future development of rural areas in the suburbs of large cities such as Warsaw. The functional and spatial changes in the neighbouring areas of the Polish capital perfectly illustrate what is also happening in other metropolises. Unfortunately, not only the main city itself but also the neighbouring municipalities experience investment pressure. This process consumes more and more areas and favours their irrational spatial and functional development, which has its negative environmental effects. In the face of threats that result from climate change, instead of looking for solutions that are logistically and technologically complicated, resources that are still available around large cities can be used. Undoubtedly, in addition to natural landscape areas, such areas may be agricultural areas. Instead of re-qualifying them, their potential can be used in creating an eco-resilient suburbs system, which is also the ecological base of the main city. The aim of the article is to draw attention to the condition, resources and adaptation possibilities of rural areas in the suburbs of Warsaw, which, like other large Polish cities, needs new ecological solutions. The study used the Statistics Poland (Główny Urząd Statystyczny) data and conclusions resulting from the literature review on the studied issue, as well as analysis of planning documents.
\end{abstract}

Key words: rural landscape, land use, urban sprawl, climate change, Warsaw suburbs, rural areas

\section{INTRODUCTION}

Contemporary globalisation processes strongly affect large cities and their immediate surroundings. After the period of political transformation, Polish cities turned out to be unprepared and, as a consequence, not resistant to negative suburbanisation processes. Poland, and other countries of the post-socialist bloc, collided with the new free market reality, which had a huge impact on trends in land use/land cover (Václavík \& Rogan, 2009; Bański, 2017). As agriculture was an important branch of the socialist economy next to industry, processes of privatisation affected mainly the agricultural sector (Bański, 2017). The suburban landscape has undergone a total transformation in recent years. Changes in the zone that is rightly called peri-urban took place extremely dynamically.

The change in traditional relations between the city and the village that has been observed for many years forces a reflection on the problems of suburban areas (Labrianidis, 2017), confirming the belief in their more dangerous than expected, multilateral degradation, including ecological, spatial and aesthetic. Although the current stage of suburban development remains at the level of bilateral, unequal "temporary benefits" derived from the free expansion of cities at the expense of the village and its open areas, the degree of this phenomenon is becoming alarming 
(Grabowska \& Wiśniewska, 2008; Jezierska-Thöle \& Kozłowski, 2008). The problem requires urgent and radical countermeasures at municipal, regional and national levels. Unfortunately, this task is extremely difficult, because it results from the spatial management system that is currently existing in Poland, caused by a deep spatial planning crisis on a local scale, and due to the continuous lack of effective mechanisms for national and regional planning that could defend the basic spatial structures, which is, in particular, the large suburban area of large cities and rural settlement space. Practically, this system makes it impossible to effectively counteract the element of urbanisation on open areas adjacent to the city, whose landscape, unless it is subject to special law (e.g. the Nature Conservation Act), is not protected in any way.

There is, therefore, an urgent need to re-evaluate the attitude to rural areas and agriculture in Poland and Europe. The oldest countries of the European Union verify old development paths, new concepts and actions are being formulated the aim of which is to protect the social side of the rural areas and renew them as an environment that is important for the future of culture and civilisation. More and more often, it is heard that "it is not technical progress, modernisation, and urbanisation, but 'ruralness' that will ultimately determine the shape of the rural suburbs and the lives of their inhabitants [own translation]" (Wieruszewska, 1988).

\section{MATERIAL AND METHODS}

The aim of the article is to draw attention to rural areas in the vicinity of large cities. The paper discusses the chosen propositions regarding the spatial development of rural areas located in the suburbs. It shows recent trends observed in the studied area and future possibilities to tackle some critical issues in order to face climate changes. The authors' own calculations based on data of the Statistics Poland were used to illustrate the processes, as well as spatial and functional analyses and the analysis of planning documents in selected municipalities. The article also presents activities and specific possible scenarios that would help to preserve the rural character of some areas in the future, which on the one hand would strengthen the solution base in response to climate change, and would also protect the cultural identity of these places.

\section{THREATS AND POTENTIAL}

The future of rural areas surrounded by large cities depends largely on the intensity and nature of their development. Recently, an increase in migration from the main city to the suburbs has been observed, which is largely caused by economic calculation, but also by longing for nature. Unfortunately, as a consequence, this causes the nature's excessive degradation. Construction decisions issued in these areas seem ill-considered and instead of protecting the assets that attract new residents, they ultimately contribute to their defragmentation and often - collapse. It turns out that the most important factor among multiple proximate drivers of landscape change is land abandonment/extensification (Plieninger et al., 2016). The observed process of shaping new social and spatial order in rural areas in the vicinity of cities should be accompanied by an inherent emphasis on the importance of landscape in shaping a new city and a new village in the suburban area. Especially since suburban areas, thanks to the strengthening of tools that emphasize and protect their urban-rural nature, have a chance to reverse or at least to stop this harmful relationship in relation to a large city in which, like a sponge, they absorb negative suburbanisation processes (Sharp \& Clark, 2008).

The studies show a progressive process of crowding out agricultural areas in the suburbs of Warsaw. This process is intensified mainly due to investor pressure, but also due to the economic unprofitability of this type of activity. The analysis of changes in the use of agricultural land for non-agricultural purposes (the so-called de-agriculture shown in local spatial development plans) shows (as of 2009) that this process is intensifying at an ever greater distance from the borders of Warsaw, which is well illustrated by the centrifugally progressing suburbanisation process in which it is clearly shifted by an average distance of $10-15 \mathrm{~km}$ in relation to the existing urbanisation areas (Śleszyński, 2012). It 
should be emphasised that the slow suburbanisation, characterised by scattering of buildings and island investment concentration, also leads to an increase in the costs of infrastructure service, which also has a great effect on the deterioration of the natural environment and the quality of life in this zone. The dynamics of progressing urbanisation processes is exposed by data on the Mazowieckie Voivodeship, where the territorial unit built-up and urbanised areas in total was 161,039 ha in 2002 , and 209,662 ha in 2018 , which means that there was an increase of $30 \%$ over the last 16 years.

The change in the function of agricultural suburban areas also has serious socio-ecological effects, because it means, among others, a partial loss of sources of income for the population living there, including reduction of natural biodiversity, the disappearance of the agricultural landscape, and traditional cultural values of rural communities. The dynamic urbanisation of villages also marginalises the quantitative and qualitative importance of the village's historical material and spiritual resources. The space of rural areas is a space that is particularly sensitive to shaping because it has its well-defined origin and sharply defined own original features and properties, shaped in a harmonious sequence of events over many centuries. It is a space devoid of cosmopolitan features, characteristic of the city, which in turn facilitates some freedom of action. The rural landscape requires extreme caution in transforming its rich natural and cultural environment. The sensitivity of the rural environment in its landscape form is manifested in macro-spatial forms of development. These are historical, strongly defined, and specific types of village planning, occurrence, and location of specific elements, such as a square, church, cemeteries, specific places related to historical events. Local forms of development are also important, such as the layout of homesteads, type, and location of home greenery. Also, in terms of intangible historical values - local traditions, legends, unwritten customs - the village landscape presents a very rich "internal" layer - imperceptible, necessary to understand the essence of the rural environment. When moving into such an area and transforming it, new residents appropriate the common and non-renewable good.
A clear example of destroying the existing traditional spatial arrangements of villages are planning concepts developed for new construction areas of intensively developing cities (Gzell, 2005). The new regions absorbed by the cities, which were formerly farmland areas, are treated as free, undeveloped areas, without significant history. Attention is not paid to the beautiful, historical geometry of the space of rural geodetic divisions. Field or block systems developed over the centuries together with balks, typical groves and pastures are completely destroyed by imposing, usually very primitive, but highly economical, secondary geodetic divisions. Thus, hectares of new, non-urban housing estates, areas designated for warehouses, technical bases, etc. are being built. Their spatial continuity is completely broken, including landscape with the place where they are erected. Contemporary globalisation processes strongly affect large cities and their immediate.

\section{THE POTENTIAL OF RURAL AREAS IN THE FIGHT AGAINST CLIMATE CHANGE}

There is currently a lively discussion on climate change and its impact on cities at a specialist level. In view of climate change, seeking rescue in the countryside of a suburban area seems like a good solution. However, it should be remembered that climate change has an impact on agricultural productivity, land use and policy (Olesen \& Bindi, 2002) as well as biodiversity (Reidsma, Tekelenburg, van den Berg \& Alkemade, 2006), and therefore it also applies to the rural areas of the suburban area, where, as a result of human activities and the progressing suburbanisation process, degradation of the natural environment progresses rapidly, and the consequences of climate change are increasingly felt and noticeable (Labrianidis, 2017).

In most municipalities, the topic of the future of rural areas is marginalised and underestimated, especially in the context of the consequences of climate change. In some cases, it could be an asset in policies to counteract their adverse effects. What is more, life in the countryside still has its supporters. Although globally, the majority of Poles still prefer living in the city $(58 \%$ declared such a choice in 2015$)-$ it is 
a significant proportion because $40 \%$ would choose to live in the town (Kowalczuk, 2015). Satisfaction for both is to build a house in the suburbs. It turns out that the town-village union, promoted at the beginning of the 20th century by Ebenezer Howard, is still attractive. That is why, when young people working in a big city want to start a family, they often choose a flat in the suburbs. Unfortunately, instead of logically protecting what in the suburbs determines its rural nature and attraction, we agree to eliminate it gradually. This is a paradox that results largely from civic immaturity and unawareness of the environmental consequences of ill-considered planning decisions.

The inevitability of depletion of natural resources and free space to invest puts pressure on reduced human expansion in the direction of transforming new areas, while at the same time turning to the maximum use of areas that have already been invested in, including ordering and restoring value - the restoration of buildings.

\section{RESULTS AND DISCUSSION}

The question about the vision of a rural landscape in the Warsaw suburbs is also, in fact, a question about the look of Polish agriculture in the future. It is certain that global agriculture will not cease to be a primary source of food and will not cease to be an important source of reproducible energy. Both natural conditions, favourable location in relation to the largest markets for agricultural products and food, as well as the possibilities of increasing the potential of agriculture in Poland, create a solid basis for the look of the suburban village to be shaped by agricultural activity in some part. It can be assumed that the importance of agriculture in the economy of the suburbs will undoubtedly be regionally and locally diversified. Therefore modifications to the overall vision of a suburban village will be necessary for different suburbs with different natural conditions and socio-economic structures.

It should be assumed that its significance as an essential confidant of a large part of local natural resources will also increase, and it will be even more diverse than today. This will require to make agricultural production systems that will meet the foreseeable environmental requirements of agricultural policy and the market more popular. In the field of agricultural technologies, it seems that primarily sustainable agriculture (organic, integrated, precise) - of growing importance, and traditional agriculture - of diminishing importance, will occur in the suburbs in the future (Wilkin, 2005). Equally, agricultural areas included in the suburban zone will also fit into the model of creating Smart Sustainable Cities - SSC (Ibrahim, El-Zaart, Adams \& 2018).

Only good quality land located in areas with favourable cultivation conditions will probably be used for agriculture. Therefore, the land in agricultural production will be of better quality, on which the efficiency of incurred expenditure, including producers' knowledge, will be the highest. The released land should be used in three directions - for afforestation and environment shaping, especially the landscape (e.g. small retention), for the development of infrastructure, mainly communication and transport, as well as the rural tourism base and low-intensity housing and service construction.

Keeping agriculture on the outskirts of cities being coherently developed will be crucial for their ecological sustainability. The proximity of agricultural areas to urban development areas should be supported and promoted. The "ruralness" will continue to lean towards "urbanity" in terms of preferred patterns and lifestyles. Only subsequent generations will manage to reverse these trends because globalisation will paradoxically increase the social (and individual) need for local anchoring. The choice of a village, in the suburbs as well, as a place of residence, can become an essential feature of the lifestyle of a large proportion of Polish people. Therefore, in the future, an increase in the number of people living in the countryside by choice can be expected, which will lead to the development of rural settlements directly around cities, but also to settlement and establishment of new establishments deep inside traditional rural areas.

Recently, quite a popular topic of urban agriculture is also gaining many supporters and practitioners 
in Polish cities. Due to traditional production methods and low consumption of chemicals, Poland can successfully produce very healthy food of high quality. Conditions are created for the development of organic agricultural production by methods that take into account the requirements of the natural environment and the needs of consumers. Global trends show that this direction will develop, forcing changes in the manner of using areas of intensive urban development (van Veenhuizen, 2006; Thomaier et al., 2015; Specht, Siebert \& Thomaier, 2016). However, this is a somewhat artificial process, given that suburban areas still offer rural areas that can keep their function and, at the same time, become a base of various activities related to agriculture, which will also preserve the natural and landscape values of the suburbs. The role of such non-urbanised rural areas may be vital in pursuing a policy of sustainable metropolitan development (La Greca, La Rosa, Martinico \& Privitera, 2011).

In suburban agriculture, the formation of two directions can be expected: multifunctional agriculture - typically family farming, using surplus family work time and producing the highest quality goods, unique and characteristic for particular regions of the country, as well as social and hobby farming, on the one hand, associated with personal goals of their owners (e.g. recreational, residences in rural areas), on the other hand, giving a certain group of people (e.g. the elderly, less resourceful people) the possibility of survival and modest living in small settlement units with natural, traditional and ecological agriculture.

It can also be concluded that the key to the development of agriculture in the suburbs of large cities will not lie in the countryside, but more and more in the city, drawing from the development of information technologies and turning to the production of energy resources, renewable energy. It should be assumed that the production of energy resources and energy, e.g. agrivoltaics, may in the 21 st century be the main stimulus for the development of agriculture and transformation of the suburban area. Among other things, thanks to such solutions, the development of agricultural land in the suburbs of large cities will also find economic justification (Monfaredzadeh \& Berardi, 2015).

\section{CONCLUSIONS}

The conditions of rapid economic and social change are not favourable for the natural and cultural diversity of the Polish countryside, which is a value worth preserving, protecting and nurturing, because they have created a situation where the original, traditional, multifunctional rural landscape underwent changes with features combining progressive and regressive succession, resulting in an unstable system that is ineffective for many reasons. This type of transformation is typical of spontaneous rural suburban areas (Plit, 2016). The effects of these changes are to reverse. They affect not only the overall landscape - its content, form, function and values but also the economic and spiritual impoverishment of local rural communities. An argument that additionally supports the need to revalorize rural areas in suburban areas is the need to react to climate change, if not reverse it, that is increasingly severely experienced by residents of large urban agglomerations. Thanks to changes in the space management system, the suburban zone can become a buffer zone, constituting the ecological base of the central city, while responding to the challenges of the 21 st century.

\section{Authors' contributions}

Conceptualization: J.Z.-W., A.G.; methodology: J.Z.-W., A.G.; formal analysis: J.Z.-W., A.G.; investigation: J.Z.-W., A.G.; resources: J.Z.-W., A.G.; writing - original draft preparation: J.Z.-W., A.G.; writing - review and editing: J.Z.-W.; funding acquisition: J.Z.-W., A.G.

All authors have read and agreed to the published version of the manuscript.

\section{REFERENCES}

Bański, J. (2017). The consequences of changes of ownership for agricultural land use in Central European countries following the collapse of the Eastern Bloc. Land Use Policy, 66, 120-130. http://dx.doi.org/10.1016/ j.landusepol.2017.04.045 
Grabowska, A. \& Wiśniewska, M. (2008). Współczesne osiedla mieszkaniowe o intensywnej zabudowie w wiejskim krajobrazie kulturowym okolic Warszawy (Statutory studies). Politechnika Warszawska, Warszawa [unpublished].

Gzell, S. (2005). Suburbanizacja a projektowe strategie urbanistyczne. In P. Lorens (ed.), Problemy suburbanizacji. Biblioteka Urbanisty 7. Warszawa: Urbanista.

Ibrahim, M., El-Zaart, A. \& Adams, C. (2018). Smart sustainable cities roadmap: Readiness for transformation towards urban sustainability. Sustainable Cities and Society, 37, 530-540. https://doi.org/10.1016/ j.scs.2017.10.008

Jezierska-Thöle, A. \& Kozłowski, L. (2008). Gospodarka przestrzenna $w$ strefie kontinuum miejsko-wiejskiego w Polsce. Torun: Wydawnictwo Naukowe Uniwersytetu Mikołaja Kopernika.

Kowalczuk, K. (2015). Kto marzy o życiu na wsi, a kto o życiu w mieście? Komunikat z Badań CBOS, 18. Retrieved from https://www.cbos.pl/SPISKOM.POL/2015/ K_018_15.PDF [accessed 05.12.2019].

Labrianidis, L. (2017). Introduction. In L. Labrianidis (ed.), The Future of Europe's Rural Peripheries (pp. 1-27). London-New York: Routledge. https://doi.org/10.4324 /9781351146647

La Greca, P., La Rosa, D., Martinico, F. \& Privitera, R. (2011). Agricultural and green infrastructures: The role of non-urbanised areas for eco-sustainable planning in a metropolitan region. Environmental Pollution, 159 (8-9), 2193-2202. http://dx.doi.org/10.1016/ j.envpol.2010.11.017

Monfaredzadeh, T. \& Berardi, U. (2015). Beneath the smart city: Dichotomy between sustainability and competitiveness. International Journal of Sustainable Building Technology and Urban Development, 6 (3), 140-156.

Olesen, J. E. \& Bindi, M. (2002). Consequences of climate change for European agricultural productivity, land use and policy. European Journal of Agronomy, 16 (4), 239-262. http://dx.doi.org/10.1016/S1161-0301(02)00004-7

Plieninger, T., Draux, H., Fagerholm, N., Bieling, C., Bürgi, M., Kizos, T., Kuemmerle, T., Primdahl, J. \& Verburg, P. H. (2016). The driving forces of landscape change in Europe: a systematic review of the evidence. Land Use Policy, 57, 204-214.

Plit, J. (2016). Krajobrazy kulturowe Polski i ich przemiany. Warszawa: Instytut Geografii i Przestrzennego Za- gospodarowania im. Stanisława Leszczyckiego Polska Akademia Nauk.

Reidsma, P., Tekelenburg, T., Berg van den, M. \& Alkemade, R. (2006). Impacts of land-use change on biodiversity: An assessment of agricultural biodiversity in the European Union. Agriculture, Ecosystems and Environment, 114 (1), 86-102. http://dx.doi.org/10.1016/ j.agee.2005.11.026

Sharp, J. S. \& Clark, J. K. (2008). Between the country and the concrete: Rediscovering the rural-urban fringe. City and Community, 7 (1), 61-79. http://dx.doi.org/10.1111/ j.1540-6040.2007.00241.x

Śleszyński, P. (2012). Warszawa i obszar metropolitalny Warszawy a rozwój Mazowsza. Warszawa: Mazowieckie Biuro Planowania Regionalnego.

Specht, K., Siebert, R. \& Thomaier, S. (2016). Perception and acceptance of agricultural production in and on urban buildings (ZFarming): a qualitative study from Berlin, Germany. Agriculture and Human Values, 33 (4), 753-769. http://dx.doi.org/10.1007/s10460-015-9658-z

Thomaier, S., Specht, K., Henckel, D., Dierich, A., Siebert, R., Freisinger, U. B. \& Sawicka, M. (2015). Farming in and on urban buildings: Present practice and specific novelties of zero-acreage farming (ZFarming). Renewable Agriculture and Food Systems, 30 (1), 43-54. http://dx.doi.org/10.1017/S1742170514000143

Václavík, T. \& Rogan, J. (2009). Identifying trends in land use/land cover changes in the context of post-socialist transformation in Central Europe: A case study of the greater Olomouc region, Czech Republic. GIScience and Remote Sensing, 46 (1), 54-76. http://dx.doi. org/10.2747/1548-1603.46.1.54

Veenhuizen van, R. (2006). Introduction. Cities farming for the future. In R. van Veenhuizen (ed.), Cities farming for the future: Urban agriculture for green and productive cities (pp. 1-19). Silang: RUAF/IIRR/IDRC.

Wieruszewska, M. (1988). Region, społeczność lokalna - renesans zainteresowań. Roczniki Socjologiczne Wsi, 22, 9-16.

Wilkin, J. (2005). O potrzebie i zasadach tworzenia wizji rozwoju polskiej wsi. In J. Wilkin (ed.), Polska wieś 2025: wizja rozwoju. Warszawa: Fundusz Współpracy, KER PAN. Retrieved from https://witrynawiejska. org.pl/data/Polska\%20wies\%202025.pdf [accessed 05.12.2019]. 


\section{ROLA OBSZARÓW WIEJSKICH W TWORZENIU EKOREZYLIENCYJNYCH PRZEDMIEŚĆ WARSZAWY}

\section{STRESZCZENIE}

Celem artykułu jest zaprezentowanie alternatywy dla przyszłego rozwoju terenów rolniczych na przedmieściach wielkich miast takich jak Warszawa. Zmiany funkcjonalno-przestrzenne terenów ościennych stolicy Polski doskonale obrazują to, co dzieje się także w innych metropoliach. Niestety presji inwestycyjnej ulega nie tylko samo miasto główne, ale także sąsiadujące z nim gminy. Proces ten pochłania coraz większe tereny i sprzyja ich nieracjonalnemu zagospodarowaniu przestrzennemu i funkcjonalnemu, co ma swoje negatywne skutki środowiskowe. W obliczu zagrożeń wynikających ze zmian klimatycznych zamiast szukać rozwiązań skomplikowanych logistycznie i technologicznie, można sięgnąć po jeszcze dostępne zasoby znajdujące się wokół dużych miast. Niewątpliwie takimi terenami, oprócz obszarów krajobrazu naturalnego, mogą być tereny rolnicze. Zamiast zmieniać ich przeznaczenie można wykorzystać ich potencjał w tworzeniu systemu ekorezyliencyjnych przedmieść stanowiących jednocześnie ekologiczne zaplecze miasta głównego. Celem artykułu jest zwrócenie uwagi na stan, zasoby i możliwości adaptacyjne terenów rolniczych w strefie suburbiów Warszawy, która podobnie jak inne duże miasta Polski potrzebuje nowych ekologicznych rozwiązań. Do badania wykorzystano dane GUS oraz wnioski wynikające z przeglądu literatury dotyczącej studiowanego zagadnienia, a także analizę dokumentów planistycznych.

Słowa kluczowe: krajobraz wiejski, gospodarka terenami, niekontrolowana urbanizacja, zmiany klimatyczne, przedmieścia Warszawy, tereny wiejskie 